\title{
Evaluation of Hereford bulls by the quality of their offspring over various periods of growing their offspring under farm conditions
}

\author{
Alexey Zelenkov ${ }^{1,2,1,}$ Galina Zelenkova ${ }^{2}$, Sergei Tresnitskii ${ }^{2}$, Pavel Bykadorov ${ }^{3}$, Natalia \\ Volgina $^{4}$ and Andrey Medvedev ${ }^{3}$ \\ ${ }^{1}$ Ministry of Agriculture and Food of the Rostov region, Krasnoarmeyskaya st., 33, Rostov- \\ on-Don, 344010, Russia \\ ${ }^{2}$ Don State Technical University, sq. Gagarina, 1, Rostov-on-Don, 344003, Russia \\ ${ }^{3}$ State educational institution of higher education of the Lugansk People's Republic \\ «Luhansk State Agrarian University», the town LNAU, 1, 91008 Lugansk city, Lugansk \\ People's Republic \\ ${ }^{4}$ State educational institution of higher education of the Lugansk People's Republic \\ «Luhansk State Pedagogical University», Oboronnaya st., 2, 91021 Lugansk city, Lugansk \\ People's Republic
}

\begin{abstract}
The greatest success in improving the breeding and productive qualities of Hereford cattle can be achieved through the use of high-value breeding bulls. The role of producers at the modern stages of beef cattle breeding has increased dramatically, so the evaluation of bulls by the quality of offspring has become an important breeding event to improve and create highly productive herds of beef cattle. At the same time, the use of bulls that are predisposed to various diseases or the deterioration of their offspring can cause irreparable negative consequences for beef cattle breeding. In the course of research work in the conditions of the farm, studies were conducted to assess the quality of bulls-producers of the Hereford breed of cattle. Evaluation of Hereford bulls by the quality of offspring in farm conditions will increase the efficiency of herd reproduction technology in beef cattle breeding, allow rational use of bulls, get a high yield of calves (90-95\%), organize the accuracy of accounting for the origin of young animals, increase the level of breeding work to improve the productive, breeding qualities of animals and create highly productive herds of Hereford cattle in a shorter time. Keywords: beef cattle breeding, Hereford breed, breeding bulls, bull evaluation, quality of offspring, creation of highly productive herds.
\end{abstract}

\section{Introduction}

${ }^{1}$ Corresponding author: zelenkovalex@rambler.ru 
At the moment the technology development and selection should be a basic requirement for the creation of such animal genotypes, which combine high production capabilities and quality with an enhanced ability to Express them in terms that do not meet adequately the physiological needs of the organism, that is, the genotype of the animals must be assigned to the whole complex of characteristics, first and foremost, the ability to develop their productive capabilities in the presence of a large number of stress factors in increasing and developing intensive technologies. An important problem of beef cattle breeding is the development of advanced management technologies, as well as breeding methods. This will allow us to improve the production of high-quality products at an accelerated pace and create new types of cattle that meet the requirements of intensive and cost-effective beef production and breeding of repair young animals. In this regard, the chosen direction of scientific research in beef cattle breeding meets the urgent requirements of beef production and rearing of repair young animals in farms of various directions and organizational structure in the Russian Federation.

The greatest success in improving the breeding and productive qualities of Hereford cattle can be achieved through the use of high-value breeding bulls. The role of producers at the modern stages of beef cattle breeding has increased dramatically, so the evaluation of bulls by the quality of offspring has become an important breeding event to improve and create highly productive herds of beef cattle. At the same time, the use of bulls that are predisposed to various diseases or the deterioration of their offspring can cause irreparable negative consequences for beef cattle breeding.

\section{Materials and Methods}

Experimental work was carried out in LLC "Aksayskoye Moloko" of the Aksay district, Rostov region. The research was conducted on a herd of Hereford cattle breeds. The herd was created as a result of purchasing breeding cattle of the Hereford breed from breeding farms in the Rostov region. We annually conduct bonitirovki, on the basis of which the selection of animals in the breeding core is carried out and specific measures are planned to improve the reproductive and productive qualities of Hereford cattle of the farm's herd.

\section{Results}

LLC "Aksayskoye Moloko" became involved in beef cattle since January 18, 2007, with the purchase of breeding 20 heifers and 5 bulls Hereford in SPK Plemzavod "Merkulovskaya" Sholokhov district of Rostov region. The quality characteristics of purchased Hereford bulls are shown in table 1, and heifers in table 2.

LLC Aksayskoye Moloko became engaged in meat cattle breeding since January 18, 2007, with purchase of breeding 20 heifers and 5 steers of Hereford breed in SEC of merkulovsky breeding plant of the sholokhovsky district of the Rostov region. The quality characteristics of purchased Hereford steers are shown in table 1, and heifers in table 2.

Table 1. Qualitative characteristics of steers purchased from SPK Plemzavod "Merkulovskaya"

\begin{tabular}{|c|l|c|c|c|c|c|}
\hline № & \multicolumn{1}{|c|}{$\begin{array}{c}\text { Nickname, } \\
\text { ind., No. }\end{array}$} & Birth date & $\begin{array}{c}\text { Age, } \\
\text { month }\end{array}$ & $\begin{array}{c}\text { Live } \\
\text { weight, } \mathrm{kg}\end{array}$ & $\begin{array}{c}\text { Exterior } \\
\text { rating, point }\end{array}$ & Class \\
\hline 1 & Brother 574 & 17.2 .2006 & 11 & 390 & 4.5 & elite \\
\hline 2 & Pound 4605 & 2.2 .2006 & 11 & 384 & 4.5 & elite \\
\hline 3 & Mirny 4625 & 18.1 .2007 & 11 & 385 & 4.5 & elite \\
\hline 4 & Mirny 6201 & 13.2 .2006 & 11 & 267 & 4.5 & elite \\
\hline
\end{tabular}




\begin{tabular}{|c|l|c|c|c|c|c|}
\hline 5 & Breeze 6207 & 2.2 .2006 & 11 & 240 & 4.5 & elite \\
\hline
\end{tabular}

Note: the sale date is January 18, 2007.

Table 2. Quality characteristics of heifers purchased from SPK Plemzavod "Merkulovskaya"

\begin{tabular}{|c|l|c|c|c|c|c|}
\hline № & \multicolumn{1}{|c|}{$\begin{array}{c}\text { Nickname, } \\
\text { ind., No. }\end{array}$} & Birth date & $\begin{array}{c}\text { Age, } \\
\text { month }\end{array}$ & $\begin{array}{c}\text { Live } \\
\text { weight, kg }\end{array}$ & $\begin{array}{c}\text { Exterior rating, } \\
\text { point }\end{array}$ & Class \\
\hline 1 & Mimosa 5052 & 23.5 .2006 & 7 & 190 & 4.5 & elite \\
\hline 2 & Spring 5334 & 17.4 .2006 & 8 & 222 & 4.5 & elite \\
\hline 3 & Mina 5336 & 12.5 .2006 & 7 & 200 & 4.5 & elite \\
\hline 4 & March 6020 & 5.5 .2006 & 7 & 220 & 4.5 & elite \\
\hline 5 & Metelitsa 6042 & 2.2 .2006 & 7 & 220 & 4.5 & elite \\
\hline 6 & Sprig 6112 & 8.3 .2006 & 9 & 220 & 4.5 & elite \\
\hline 7 & Sprig 6114 & 20.4 .2006 & 8 & 245 & 4.5 & elite \\
\hline 8 & Cherry 6116 & 15.03 .206 & 9 & 224 & 4.5 & elite \\
\hline 9 & Cherry 6202 & 15.04 .206 & 9 & 200 & 4.5 & elite \\
\hline 10 & Lira 6210 & 1.04 .2006 & 8 & 232 & 4.5 & elite \\
\hline 11 & T-shirt 6222 & 15.03 .2006 & 9 & 260 & 4.5 & elite \\
\hline 12 & Lassie 6304 & 20.04 .2006 & 8 & 239 & 4.5 & elite \\
\hline 13 & Lassie 6308 & 5.04 .2006 & 9 & 248 & 4.5 & elite \\
\hline 14 & Mulka 6316 & 23.04 .2006 & 8 & 229 & 4.5 & elite \\
\hline 15 & Milka 6318 & 12.04 .2006 & 8 & 232 & 4.5 & elite \\
\hline 16 & Violeta 6320 & 15.04 .2006 & 8 & 212 & 4.5 & elite \\
\hline 17 & Burenka 6330 & 18.04 .2006 & 8 & 240 & 4.5 & elite \\
\hline 18 & Verbochka 6332 & 15.04 .2006 & 8 & 238 & 4.5 & elite \\
\hline 19 & Murka 6354 & 15.04 .2006 & 8 & 219 & 4.5 & elite \\
\hline 20 & Chub 6408 & 10.04 .2006 & 8 & 220 & 4.5 & elite \\
\hline
\end{tabular}

Note: the sale date is January 18, 2007.

The imported heifers belonged to two lines: Baron 2344-14 heifers and Label 413-6 heifers. On the line of the Baron, they were the daughters of two bulls: pirate 3841 (its live weight in $3 \mathrm{~g}$. $700 \mathrm{~kg}$, exterior rating was 95 points, complex class-elite-record) - 9 heifers and bull Indus. No. 3984 ( 2 g. - 750 kg-90-elite-record) - 5; on the Label line-6 heifers, whose father was the manufacturer Leaf $2615-3 \mathrm{~g}$. $-780 \mathrm{~kg}-90$ points-elite-record).

In order to avoid the harmful influence of related mating, on March 29, 2011, specialists purchased three more purebred breeding bulls of the Hereford breed from the breeding farm "Rodina" of the Krasnogvardeysky district of the Stavropol territory. The characteristics of purchased bulls are shown in table 3 .

Table 3. Characteristics of purchased bulls SPK Rodina of the Stavropol territory 


\begin{tabular}{|c|c|c|c|c|c|c|}
\hline № & $\begin{array}{c}\text { Nickname, } \\
\text { ind., No. }\end{array}$ & Birth date & $\begin{array}{c}\text { Age, } \\
\text { month }\end{array}$ & $\begin{array}{c}\text { Live } \\
\text { weight, kg }\end{array}$ & $\begin{array}{c}\text { Exterior } \\
\text { rating, point }\end{array}$ & Class \\
\hline 1 & 01003 & 7.01 .2010 & 14 & 445 & 90 & elite-record \\
\hline 2 & 01202 & 13.01 .2010 & 14 & 475 & 90 & elite-record \\
\hline 3 & 03213 & 14.03 .2010 & 12 & 430 & 90 & elite-record \\
\hline
\end{tabular}

Note: the sale date is March 29, 2011.

The purchased Hereford bulls were genealogically descended from the same line of FORDER 1915126. The father of two bulls-01202 and 03213 was the Favorite bull 21004 (at the age of 5, he had a live weight of $940 \mathrm{~kg}$ and a complex class-elite-record), in which all the ancestors on the four rows of the pedigree (on the paternal side) had a complex classelite-record. On the maternal side, the mother of bull 01202 was rated first class on the set of characteristics, and the great-grandmother, respectively, was rated elite, and on the paternal side, elite and elite-record; accordingly, on the paternal side of the pedigree - class elite, elite and elite-record.

Bull 01003 on the paternal side of the pedigree had the ancestors of all rated class eliterecord, and on the maternal side: mother and grandmother-rated class elite, and greatgrandmothers-first class and elite-record. Bull 03213 had an elite mother (live weight 600 $\mathrm{kg}$ at the age of 7 years $)$ and a grandmother $(4 \mathrm{~g}$. weight $490 \mathrm{~kg})$, and the great-grandmother was evaluated by the first class, first class. On the maternal side of the pedigree, the grandfather was rated elite-record class (live weight $921 \mathrm{~kg}$ ), and his mother had the eliterecord class on the complex of signs, and his father - elite class.

This is the quality side of the first imported bulls in LLC "Aksayskoye Moloko", which were used in a herd of cows.

To exclude related breeding in the Hereford herd in LLC "Aksayskoye Moloko" May 26, 2015 it was imported eight high-class bulls: seven class elite-record and one of the elite nucleus of JSC "Belokamenskoe" Apanasenkovskogo district, Stavropol territory. The characteristics of these high-value bulls are shown in table 4 .

Table 4. Characteristics of purchased bulls from JSC "Belokopanskoe"

\begin{tabular}{|c|c|c|c|c|c|c|}
\hline$№$ & $\begin{array}{c}\text { Nickname, } \\
\text { ind., No. }\end{array}$ & Birth date & $\begin{array}{c}\text { Age, } \\
\text { month }\end{array}$ & $\begin{array}{c}\text { Live } \\
\text { weight, kg }\end{array}$ & $\begin{array}{c}\text { Overall score/for } \\
\text { exterior, point }\end{array}$ & Class \\
\hline 1 & 3220 & 28.12 .2013 & 17 & 415 & $84 / 20$ & elite-record \\
\hline 2 & 3223 & 28.12 .2013 & 17 & 410 & $88 / 20$ & elite-record \\
\hline 3 & 3229 & 24.12 .2013 & 17 & 430 & $85 / 20$ & elite-record \\
\hline 4 & 3237 & 6.12 .2013 & 17 & 410 & $84 / 20$ & elite-record \\
\hline 5 & 3255 & 15.12 .2013 & 17 & 410 & $76 / 20$ & elite \\
\hline 6 & 3386 & 6.12 .2013 & 17 & 430 & $81 / 20$ & elite-record \\
\hline 7 & 3465 & 28.12 .2013 & 17 & 465 & $94 / 20$ & elite-record \\
\hline 8 & 3703 & 15.12 .2013 & 17 & 460 & $94 / 20$ & elite-record \\
\hline
\end{tabular}

Note: the sale date is May 26, 2015.

All steers were distinguished by good health and a beautiful exterior, characteristic of the Hereford breed. The first three bulls (3220, 3223 and 3229) were related, as they belonged to the same famous Hereford line, the famous ancestor of The FORDER factory 
line 1915126. In addition, the first five steers (individual numbers: $3220,3223,3229,3237$ and 3255 half-brothers, descend from the same father, his Indus. No. 44154415 BLK). This father had high indicators of a complex assessment: live weight in 6 years $967 \mathrm{~kg}$, an assessment of the exterior of meat articles 97 points, a complex class elite-record. At the same time, it has a high rating not only for its own productivity, but also for the quality of its offspring.

Analyzing the given data, the father of the bull-producer 4415 BLK-4415, from which LLC "Aksayskoye Moloko" was delivered to 5 bulls, we can assume that these steers will leave a noticeable mark in the formation of the herd on the farm. When assessing the bull's own productivity of 4415 , we note that he surpassed his father in live weight at 15 months of age by $18 \mathrm{~kg}$ or $103.83 \%$, and in terms of his own productivity, growth energy during the evaluation period from 8 to 15 months of age by $61 \mathrm{~g}$ or $5.14 \%$. When assessing the quality of offspring, bull 4415 received an index of $105 \%$ or $5 \%$ higher, and surpassed its peers (table 5).

Table 5. Evaluation of bull 4415 BLK-4415, his father and sons

\begin{tabular}{|c|c|c|c|c|c|c|}
\hline Degree & \multicolumn{6}{|c|}{ By your own productivity } \\
\cline { 2 - 7 } & $\begin{array}{c}\text { live } \\
\text { weight, } \\
\mathrm{kg}\end{array}$ & $\begin{array}{c}\text { average daily } \\
\text { growth, } \mathrm{g}\end{array}$ & $\begin{array}{c}\text { meat } \\
\text { forms, } \\
\text { point }\end{array}$ & $\begin{array}{c}\text { body type } \\
\text { and } \\
\text { appearance }\end{array}$ & class & index \\
\hline Bull & 488 & 1247 & 56 & 5 & elite-record & 107 \\
\hline $\begin{array}{c}\text { Father of } \\
\text { the bull }\end{array}$ & 470 & 1186 & 56 & - & elite-record & 108 \\
\hline Sons & $\begin{array}{c}\text { average } \\
\text { live } \\
\text { weight, } \\
\mathrm{kg}\end{array}$ & $\begin{array}{c}\text { average daily } \\
\text { growth, g }\end{array}$ & $\begin{array}{c}\text { The quality } \\
\text { forms, } \\
\text { point }\end{array}$ & $\begin{array}{c}\text { of the progeny } \\
\text { appearance } \\
\text { and }\end{array}$ & class & index \\
\hline 15 & $\begin{array}{c}438 \\
\mathrm{n}\end{array}$ & 1120 & 54 & 5 & elite-record & 106 \\
\hline
\end{tabular}

His sons in the herd of LLC "Aksayskoye Moloko" will undoubtedly show an advantage of at least $5 \%$, or even more, when evaluating their own productivity, when compared with their peers.

Even higher indicators of their own productivity can be expected from bull calves, whose individual numbers are 3386, 3465 and 3703, which have a higher live weight 10-40 $\mathrm{kg}$ higher than their peers purchased from JSC "Belokopanskoe".

\section{Conclusions}

Thus, we can say that in LLC "Aksayskoye Moloko" is a great, interesting and successful operation of beef cattle breeding with the aim of creating highly productive herds of Hereford and are used for this high-value bulls purchased in the best breeding plants and pedigree as Rostov region, Stavropol territory.

\section{References}

1. A. Zelenkov, A. Ermakov, G. Zelenkova et al., E3S Web of Conferences 135, 01088 (2019)

2. A. Zelenkov, A. Ermakov, G. Zelenkova et al., IOP Conf. Series: Earth and Environmental Science 403 (2019) 012020 
3. A. Zelenkov, G. Zelenkova, A. Ermakov et al., E3S Web of Conferences 164, 06032 (2020)

4. D.W. Moser, National Beef Cattle Evaluation Consortium «Beef Sire Selection Manual Second Edition», 2, p. 65-68 (2012)

5. J.A. Torres-Vázquez, Journal of Animal Science, 94 (1), p.21-27 (2016)

6. X.H. Zhao et.al., Experimental Biology and Medicine, 240 (9), p. 1152-1157 (2015)

7. A. Zelenkov, P. Zelenkov, G. Zelenkova, Vestnik OrelGAU. 3 (54), p.79-85 (2015)

8. J. Xia, et al., Mammalian Genome, 27 (5-6), p.246-255 (2016)

9. J.L. Williams et al., J. ANIM SCI, Vol. 88, No. 2, p.460-466 (2010)

10. K.J. Thornton et al., Annals of Animal Science, 15 (2), p.349-358 (2015)

11. A. Zelenkov, P. Zelenkov, G Zelenkova, Bulletin of the Don state agrarian University 4-1 (14), p. 35-41 (2014)

12. A. Ludwiczak et al., Proceedings of SPIE - The International Society for Optical Engineering, 9631 (2015)

13. P. Zelenkov, A. Zelenkov, G. Zelenkova, Veterinary pathology 3-4 (49-50), p. 15-19 (2014)

14. D. Lim, N.K. Kim, S.H. Lee, H.S. Park et al., International Journal of Genomics, 708562 (2014)

15. M. Hersom, A. Imler, T. Thrift, J. Yelich, J. Arthington, Journal of Animal Science, 93 (6), p.3169-3178 (2015) 